\title{
The Role of Taxes in Economic Development of Kosovo
}

\author{
Artan Nimani \\ artannimani@gmail.com \\ Kolegji Biznesi Gjakovë, Kosovë
}

\begin{abstract}
To achieve prosperity and political stability, national governments aimed at achieving economic equilibrium. The government uses various instruments to stimulate economic growth, reduce unemployment and to achieve macroeconomic objectives. In the context of slow economic growth in recent years and fiscal pressures, Kosovo faces the complex challenge of economic development. Unemployment remains at a high level. Demand for labor is still very low and create an environment that will favor the formation of stable work places is a challenging task that requires a multidimensional reforms in the economy. This paper addresses the impact of fiscal policy on reducing unemployment, increasing investment and consumption to generate sustainable economic growth.
\end{abstract}

Keywords: fiscal policy, unemployment, investment, consumption, economic growth.

\section{Introduction}

Kosovo is one of the last countries in Europe to switch to a market economy. The transition process started from a very difficult starting point. Kosovo has a long history of state domination of economic and financial systems, which led to a degree, volume and limited experience of the private economy. During the years after the war, an economic growth of symbolic character, which have been attributed mainly remittances, investment in infrastructure and privatization. Investment, despite continued growth, deemed insufficient to boost domestic production. This pattern of growth has not been able to meet the development needs of the state and failed to dismantle the better standard of living for citizens considering that unemployment or poverty or are not reduced. (Progress Report on Kosovo, European Commission 2011) However, Kosovo needs to significantly accelerate its growth to reach regional income levels. According to World Bank estimates 18, Kosovo's economy should have increased by 10 percent per year for a decade in order to reach the level of earnings Albania, always claiming that Albania's economy continues to growth of 5.5 percent on an annual basis during this period. ${ }^{1}$

\section{SHORT PRESENTATION OF FISCAL POLICY}

Fiscal policy consists in the use of taxes and government spending as a means to influence the macroeconomic indicators of the country. Government spending affect the overall level of spending economy, including the level of GDP and consequently the level of employment, inflation, etc. Fiscal policy affects directly or indirectly in the domestic economy.

Decisions taken in fiscal policy are not easy because changing one variable can change cause other variables and takes the wrong direction, so fiscal policy is regarded as a complex area which is necessary to analyze in detail. The tax system in Kosovo is faced with ideas on various challenges. Free to highlight any specific problem within the system, some of the flaws are quite evident and do not require significant input to resolve.

\footnotetext{
1 World Bank, Doing Business Report / 2013
} 
Others require radical reform in general proportions. Tax cuts made by this government has been a good place in postwar Kosovo. Such a decision has helped the development of businesses and the distribution of the tax burden to all participants. Higher positivity comes from the reduction in corporation tax from 20 to $10 \%$.

It made Kosovo more attractive in the global market. However, the wave of optimism remained oblivious of the VAT increase from $15 \%$ to $16 \%$. Although the increase was proclaimed as "only $1 \%$ " the truth is that VAT increased by 1 percentage point and it is equal to $6.6 \%{ }^{1}$

Taxes in Kosovo consists of three types of taxes:

\section{Value Added Tax}

\section{Tax Corporate Income}

\section{Personal Income Tax}

These types of taxes are amended in order to simplify and providing tax relief, reducing and adjusting tax rates to the level of countries in the region. It is the harmonization of legal provisions between species in Personal Income Tax and Corporate, as well as the harmonization of the VAT Act, the European Community Directive on VAT. They drafted and adopted bylaws for implementation of tax laws.

To understand the context of decision making taxpayers to meet their tax obligations, you will need to identify the main elements behind this decision. The OECD has carried out a study, which showed that the decisions of taxpayers affected primarily by five factors:

The economic situation: Taxes are ultimately money, however, it is important not to forget that the economy overall is not decisive factor, as people generally think. The decision to meet or not to meet obligations may also be obtained for noneconomic reasons.

Rates: personal and social norms play a major role in decision making process. Therefore, it is important that TAK be able to create debate and knowledge among the public regarding the fulfillment of tax obligations.

Remedy: By making an example of those who violate the rules, is a very important push for the fulfillment of tax obligations and historically was used by tax administrations. However, it is important to remember that the controls and setting the fines are limited numerous instruments fulfilling, because they rarely reach fulfillment in the long run. Also, the controls are very costly to the tax administration.

Opportunities: The ease or difficulty that accompanies the respect or disrespect of taxes is very important in choosing who makes the taxpayer. So, whether it becomes easy fulfillment of obligations and the hard failure, it plays a central role in the work of the TAK.

Justice: The impression that taxpayers about the tax system and the implementation of tax legislation by the tax administration, it is important for the readiness to implement the tax rules. Taxpayers should feel they are treated well and ensure that TAK take measures against those who try to avoid compliance.

\section{Fiscal Business}

Fiscal cash registers are only one of many elements that help fight against tax evasion. Above all he is a human factor that determines the spread or stop this phenomenon. Kosovo Tax Administration has the lowest number of tax inspectors per capita in all of Europe. The same multiple take lower wages than their counterparts in the region and more towards the

12. Tax Administration, Performance Strategy 2012-2015 
power of businesses in the absence of financial police administrators are simply helpless. Besides human capital and factors such as law enforcement voluntary willingness, trust in institutions, government spending, corruption 20 and different rates are elements that define social business decision whether or not to meet fiscal obligations.

\section{Understanding fiscal obligations and business community}

Results of studies undertaken by Ri-invest show that tax compliance has a positive relationship with the size of firms. Large firms tend to be more in line with taxes than small firms.

In addition, women entrepreneurs tend to be less evasive than their counterparts, businesses with high cash transactions evade more, while corruption tends to affect a considerably as well as negatively levels of compliance with taxes. Institutional weakness undermines compliance with taxes. On average, business is inspected for four days in the whole year of tax administration, customs and two days of nearly five days by municipal officials. Kosovo has the lowest number of tax inspectors in 1,000 people in the region. Only 350 inspectors working in the field. Kosovo, recently entered into a costly process and fiscalisation complex, with the aim to provide each business with apparatus for recording the money quite opposed by business owners and is still less than a quarter of the way along during the implementation phase. (Riinvest 2011).

\section{Acute problems of fiscal policy}

Firm size is related to the positive correlation in terms of fiscal barriers to business development. Average firms see tax administration and tax rates quite high barrier than see small firms and micro-firms.

This reinforces the general belief that the tax administration is targeting large companies due to insufficient human resources at their disposal, with the aim of optimizing revenue collection with a certain capacity. Interviews with business associations in Kosovo reveal that larger companies complain far more about unfair treatment, lengthy inspections or unfair sentences by tax inspectors, as opposed to small firms who are rarely in direct contact with tax collectors. In connection with tax requirements, large companies highlight the importance of VAT collection as a barrier to their expansion 1 .

VAT related matters on the basis of Kosovo, the majority of investment and raw materials are required to carry a burden of 16 percent of VAT at the border, before going any operation that investment results. According to business associations, such a burden increases difficulties with cash flow to businesses and, consequently, the need to go into borrowing obligations with high interest rate (14-16 percent on average). This, in turn obstructs cash flow sustainability, growth potential and the creation of new jobs. Such a burden, however, is less present 21 among small firms, as they are obliged by law to pay a fixed fee. Therefore, tax rates and tax administration appear at the bottom of the list of barriers for small firms, and higher ranking among larger firms (UNDP, 2012).

\section{EVASION OF TAXES}

Results of the study show that the level of tax evasion in Kosovo is around $39 \%$, roughly the same as other countries, the most in Albania and Bosnia during $1999-2005$. However, it is significantly beyond well-established post-transition countries and their average of $12.4 \%$.

Firms which generally deal with less visible transactions, and focused on money (given the lack of control / audit sufficient and fine mechanisms in Kosovo) are the most frequent evaders taxes - and evasion / avoidance It connects well with the degree of informality in the sector.

The largest rate of evasion is the tertiary sector (so far wider sector in Kosovo) and in the primary - showing again the challenges facing agricultural growth and rural worker protection. Tax evasion / tax in Kosovo is equally damaging portfolio / public financial feasibility, market expansion and contract. This is mainly the result of two factors - the high cost of financial

\footnotetext{
1 The Central Bank of Kosovo financial sector report, 2012
} 
and psychological violence in accordance with the rules too complicated, and a large informal economy, which operates outside the system secure.

Chamber of Commerce considers tax evasion to be one of the generators of the single most important unfair competition (Rukiqi 2011). General reflection on fiscal trends in Kosovo GDP for 2012 was 4.911 billion $€$, while for 2013 is expected to be 5.234 billion $€$. This upward trend will continue in the same course and for 2014 according to World Bank projections. The value of GDP in Kosovo is $0.01 \%$ of the world economy (The World Bank Group). According to the World Bank, Kosovo's GDP amounted averaged 4. 13 billion US dollars from 2000 to 2011, reaching a record high total on 6.45 billion in December 2012 and the lowest on record 1. 86 billion in December 20001.

\section{Termination}

The government uses various instruments to stimulate economic growth, reduce unemployment and to achieve macroeconomic objectives. Fiscal policy is one of the most important policies that can positively affect the reduction of unemployment. Kosovo and Albania are the expansion to slow, so every decision has a huge impact on the progress of economic activity across the country. It is worth mentioning that while failure to pay taxes critically negatively affects economic stability, about $9 \%$ of business taxpayers consider tax evasion as a weapon ever to survive.

Fiscal developments during the first quarter of 2013 were more positive in the regular budget revenues. Total revenues at the end of the first quarter of the year recorded about 274 million $€$, a figure that is lower to about $4.6 \%$ compared with the first quarter of 2012. Revenues from customs, as the main source of total revenues, over the first quarter of the year marked 147. 2 million, a figure which is higher by about 3. $3 \%$ compared with the same period last year. It reduces the capacity of the government to distribute revenues effectively, and to make capital investments. Creates an unfair advantage for companies of non-compatible, expands investment incentives to operate outside the law. This has a secondary effect on defenses odd employees and the creation of decent work. It is also an indicator of the quality of the relationship between the private sector, government and society. Being connected to form a chain of addressing these issues deserve the right to improve the business climate. Fiscal policy held in Kosovo, as well as in Albania is expansive fiscal policy. Government expenditures are too high and the budget deficit is not small. The state budget allocated to different areas in the country where the main subject of years now is infrastructure. Kosovo has not paid attention to public debt-raising because the consequences are long term and can lead to state bankruptcy. When asked whether fiscal policy can mitigate unemployment, the classical economists think otherwise, while they Kejnsy say yes. Fiscal policy can alleviate but not solve the unemployment problem. If we do not take into account potential problems as "Crowding Out" in an economy in recession, expansionary fiscal policy to reduce taxes and government spending can increase GDP, creating jobs, prosperity and economic welfare. ${ }^{2}$

\section{REFERENCES AND BIBLOGRAPY:}

[1] Elmer G. Wiens: Classical and Keynesian AD-AS model;

[2] Tax Administration, Performance Strategy 2012-2015

[3] World Bank, Doing Business Report / 2013;

[4] The Central Bank of Kosovo financial sector report, 2012;

[5] CBK Balance of Payments, 2012;

[6] Statistical Office of Kosovo, the Report for 2012;

[7] Statistical Office of Kosovo, Foreign Trade Statistics 2012;

[8] Hansen, Bent (2003): The Economic Theory of Fiscal Policy, Volume 3;

\footnotetext{
1 The Central Bank of Kosovo financial sector report, 2012, page 17-19

2 RIINVEST, Industry Strategy, 2010;
} 
[9] RIINVEST, Industry Strategy, 2010;

[10] Ri-invest Enterprise Barriers Survey, 2011;

[11] Romer, David (2000) - Advanced Microeconomics;

[12] UNDP Public Pulse Report, 2012;

[13] UNDP, Kosovo Human Development Report, 2012

[14] World Bank, Doing Business 2014 Economic Profile - South, 2013 